\title{
ROS1 Negative
}

National Cancer Institute

\section{Source}

National Cancer Institute. ROS1 Negative. NCI Thesaurus. Code C153498.

An indication that expression of ROS1 has not been detected in a sample. 